\title{
Røyk, risiko - og rette ben
}

\author{
Røykere er utsatt for kirurgiske komplikasjoner. Behandlingen av den enkelte må likevel ikke være basert \\ på grupperisikoen.
}

På ortopedforeningens høstmøte nylig var blant annet postoperative komplikasjoner og resultater ved protesekirurgi hos røykere et tema. Det er hos dem som røyker vist økt forekomst av tidlige postoperative komplikasjoner (1) og ved hofteprotese flere dype infeksjoner, økt revisjonsrate og risiko for proteseløsning (2). Selv om dette er observasjonsstudier som ikke kan si noe sikkert om årsakssammenhenger, er det altså økende kunnskap om at røyking har negative helsekonsekvenser også når det gjelder ortopediske inngrep.

Preoperative tiltak for røykekutt, som rådgivning og preparater for nikotinerstatning, før kirurgi generelt (3) og protesekirurgi spesielt har gitt reduksjon av postoperative komplikasjoner (4). Den amerikanske ortopedforeningen kom i november 2015 med en oppfordring om å ta opp røykeslutt med pasientene preoperativt samt tilby nikotinsubstitusjonsbehandling og eventuelt annen farmakologisk støttebehandling (5).

I et intervju med Dagens Medisin i etterkant av høstmøtet kommer det frem at leder av Norsk ortopedisk forening, Jon Olav Drogset, ønsker at det skal stilles strengere krav til røykfrihet i forbindelse med kirurgi (6). Kirurgene bør «stå samlet» overfor pasientene i kravet om røykfrihet. Han fremholder at det er fire ganger hyppigere med beninfeksjon hos røykere ved ortopediske inngrep. Videre at "preoperativ røykeslutt reduserer komplikasjoner med femti prosent og reduserer lengden på sykehusoppholdet».

I samme intervju uttaler Kjetil Hvaal, overlege ved Oslo universitetssykehus, at det kan være aktuelt å tilby konservativ behandling til røykere som ikke slutter, for eksempel fysioterapi i stedet for leddprotese eller spesialsko i stedet for operasjon ved hælbrudd.

Saken illustrerer to poenger. For det første: Hva er utgangsrisikoen, og menes det absolutt eller relativ risiko? Forskningen på feltet er ikke entydig. En metaanalyse viste for eksempel at røykere var mer utsatt for komplikasjoner etter hoftekirurgi, men at de ikke hadde lengre liggetid (2). Den samme metaanalysen viste $2,4 \%$ risiko for dyp infeksjon ved hofteprotesekirurgi hos røykere, mot $1,5 \%$ generell risiko hos alle som ble operert. Den relative risikoøkningen er altså dramatisk høyere, men vil en absolutt risikoøkning på $0,9 \%$ være grunn god nok til å nekte en pasient behandling?

For det andre: Man bør forvente at en leder i en spesialistforening og en overlege ved et universitetssykehus trår varsomt når de ytrer seg offentlig om et betent tema som dette. Deres ord har stor påvirkningsmakt på den helsepolitikk som praktiseres i det ganske land og kan skape presedens når det gjelder hvilken behandling som skal tilbys røykere. En rekke andre grupper i samfun-

\section{«Det kan virke som}

\section{om tanken at enhver \\ er skyld i sin uhelse, har fått økt klangbunn i samfunnet»}

net - overvektige, diabetespasienter, ikkemosjonister, kampsportutøvere - er alle på sitt vis ekstra utsatt for skade og sykdom.

Det norske helsevesenet er imidlertid tuftet på ideen om lik behandling til oss alle, uavhengig av hvilken egenandel vi har betalt gjennom våre livsvalg.

I hvert enkelt tilfelle vil det alltid være en medisinsk vurdering om hvorvidt inngrepets risiko oppveier mulig effekt. Men å ta beslutninger om behandling på gruppenivå hos for eksempel røykere når det gjelder ortopedisk kirurgi, kan jeg ikke se at man har vitenskapelig grunnlag for. Siden det er påvist en klar korrelasjon mellom sosioøkonomisk status og tobakksbruk, med høyere forekomst av røyking hos lavt utdannede (7, 8) og psykisk syke (9), har et slikt forslag også en betenkelig sosial dimensjon.

Det kan virke som om tanken at enhver er skyld i sin uhelse, og at man i større grad må stå til ansvar for sine livsstilsvalg, har fătt økt klangbunn i samfunnet. Som leger bør vi stå samlet mot denne tankegangen. Ortopediforeningen kan i sin iver etter å fremme et godt formål - å få pasienten til å slutte å røyke - ha kommet i konflikt med solidaritetstankegangen den norske helsetjenesten er tuftet på.

\section{Ketil Slagstad}

ketil.slagstad@legeforeningen.no

Ketil Slagstad (f. 1983) er lege og medisinsk redaktør i Tidsskriftet.

Forfatter har fylt ut ICMJE-skjemaet og oppgir ingen interessekonflikter.

\section{Litteratur}

1. Møller AM, Pedersen T, Villebro $\mathrm{N}$ et al. Effect of smoking on early complications after elective orthopaedic surgery. J Bone Joint Surg Br 2003; 85: $178-81$

2. Teng $S$, Yi C, Krettek $C$ et al. Smoking and risk of prosthesis-related complications after total hip arthroplasty: a meta-analysis of cohort studies. PLOS ONE 2015; 10: e0125294.

3. Møller AM, Villebro N, Pedersen T et al. Effect of preoperative smoking intervention on postoperative complications: a randomised clinical trial. Lancet 2002: 359: $114-7$

4. Thomsen T, Villebro N, Møller AM. Interventions for preoperative smoking cessation. Cochrane Database Syst Rev 2014; 3: CD002294.

5. Canale ST, Kelly FB, Daugherty K. Smoking Threatens Orthopaedic Outcomes. AAOS Now. November 2015. Volume 9, Number 11. www.aaos.org/ news/aaosnow/jun12/cover2.asp (15.11.2015).

6. Askvik K. Ortopedene ønsker røykfrie pasienter. www.dagensmedisin.no/artikler/2015/11/10/ ortopedene-onsker-roykfrie-pasienter/ (15.11.2015).

7. Folkehelseinstituttet. Røyk og snus - faktaark med statistikk. www.fhi.no/tema/royking-og-snus/ fakta-om-royking-og-snus (15.11.2015).

8. Lund KE, Lund M. Røyking og sosial ulikhet i Norge. Tidsskr Nor Lægeforen 2005; 125: 560-3.

9. Lien L, Huus G, Morken G. Psykisk syke lever kortere. Tidsskr Nor Legeforen 2015; 135: 246-8.

Mottatt 24.11. 2015 og godkjent 10.12. 2015. Forfatteren er redaktør i Tidsskriftet. Manuskriptet er derfor behandlet eksternt avsetteredaktør Michael Bretthauer.

Publisert først på nett. 